\title{
Regional and Municipal Budget Balance as a Tool of Facilitating Economic Security Based on the Example of the Krasnoyarsk Territory (Krai)
}

\author{
Edham Sh. Akbulatov, Anna A. Luk'ianova \\ and Elena S. Kononova* \\ Reshetnev Siberian State University \\ of Science and Technology \\ 31 Krasnoyarsky Rabochy, Krasnoyarsk, 660037, Russia
}

In modern conditions, the problems of economic security of socio-economic systems of various levels are in the focus of attention of Russian and foreign scientists. These problems are particularly acute for territories that have a pronounced source of raw materials and underdeveloped high-added value industries. Economic security of the city and the region cannot be ensured without due regard to the sectoral structure of the economy and the balance of budgets of all levels. An important indicator of the budget balance is the structure of the regional budget revenue, or, particularly, the structure of tax revenues to the budget, as well as the expenditure structure.

The article discusses the distinctive formation features of revenue and expenditure parts of the regional and local budgets, analyses the most typical sources of revenue for different territories.

The consolidated budget structure for the region and some municipalities based on the example of the Krasnoyarsk Territory (Krai) is analysed. The dynamics of revenues and expenditures is considered, the limitations stipulated by the regional law on intergovernmental relations are examined. As a result of the study, the authors arrived at the conclusions about the lack of balance between the analysed budgets, their inconsistency with the needs of the region, and, as a result, the existing threats to the economic security of the territory in question.

The article contains recommendations on the development of economic activities in the Krasnoyarsk Territory that take into account the specifics of the studied region and that can improve the balance of local and regional budgets.

Keywords: state budget, regional budget system, municipal budget, budget planning, budget balance, economic security.

Research area: economics.

(C) Siberian Federal University. All rights reserved

* Corresponding author E-mail address: kononova es@sibsau.ru

ORCID: 0000-0003-4181-4468 (Akbulatov); 0000-0003-0322-8556 (Luk'ianova); 0000-0002-3211-7196 (Kononova)

This work is licensed under a Creative Commons Attribution-NonCommercial 4.0 International License (CC BY-NC 4.0). 
Citation: Akbulatov, E.Sh., Luk'ianova, A.A., Kononova, E.S. (2019). Regional and municipal budget balance as a tool of facilitating economic security based on the example of the Krasnoyarsk territory (Krai). J. Sib. Fed. Univ. Humanit. soc. sci., 12(4), 514-529. DOI: $10.17516 / 1997-1370-0406$.

\section{Introduction}

Today the territorial economic security mechanism development problem is among the urgent ones. Russian National Security Doctrine, approved by the Decree of the President of the Russian Federation No. 683 dated 31.12.2015, determines its key task as the elimination of threats generated by disproportion in the regional development through enhancing the independence of their socio-economic development, creation of an advantageous investment climate, encouragement of entrepreneurship and strengthening the fiscal capacity (Decree of the President..., 2019). Economic capacity of a territory is integral to the sectoral composition of economy and budget balance of all levels.

There is a number of factors influencing the budget system balance: independence of budgets of various levels, allocation of incomes and expenses, and, particularly, centralization of the income at the federal level and distribution of the expenditure powers between the regional and municipal budgets, implementation of the fiscal equalization policy and subsidization of certain territories. A significant impact on the balance of the regional and municipal budgets is made by such parameters as the sectoral structure of the economy, fiscal health of enterprises and organizations located in the territory of the region or municipal entity, share of working-age population and employment rate. One of the symptoms of budget disequilibrium is deficit, i.e. domination of expenses over income. It should be noted, however, that budget deficit problem is quite urgent for our state. In the year 2018, the total budget deficit of ten Russian regions exceeded three billion Roubles. The greatest deficit is found in the budgets of the Penza and Kostroma Oblasts, Trans-Baikal and Altai Territories and other regions. The said entities are similar in the lack of large industrial enterprises manufacturing high value-added products in the territory, concentration of economy in the service and trade sectors.

The budget balance problem is also up-to-date for the territories with a pronounced source of raw materials and underdeveloped high added value industries. The disbalance of regional economy, caused by the concentration of capital and investment in the industries with wide profit margin based on the natural resource royalty, developed 
back in the 1990-s, has not been overcome yet. Therefore, an important indicator of the budget system balance is the structure of regional revenues, or, to be more precise, the structure of tax revenues to the budget, as well as the structure of expenditures. The balance between the revenues, operating and capital expenditures is the key priority of the budget policy of any level. Increasing own incomes and finding expenditure optimization solutions are the main challenges of economic security faced by regions and municipalities.

The balance problem of regional and municipal budgets has been thoroughly studied by many contemporary researchers. The crisis phenomena in the regional budget systems are considered in the works by N.V. Zubarevich (Zubarevich, 2016, 2015); regional budget balance and debt are studied by A. Tabakh, D. Andreeva (Tabakh, Andreeva, 2015); the results of research of interregional differences in the approach to budget management are presented in the works by N. Ankidinov, A. Cherniavsky, A. Chepel' (Ankidinov, Cherniavsky, Chepel', 2016), inter-budgetary relations within city agglomerations, as well as methodologies of various level budget development are analysed in publications by S.N. Grib, S.N. Makarova, D. A. Maslodudov (Grib, Makarova, Maslodudov, 2012; Makarova, 2012), results of research of methodological approach to inter-budgetary distribution of tax and regional budget condition assessment are formulated in the works by M.A. Pechenskaia, T.V. Uskova, A.A. Kuklin, K.S. Naslunga (Kuklin, Naslunga, 2018; Pechenskaia, Uskova, 2016). The listed researches have solved numerous theoretical and applied tasks, but the problems of interconnection between the budget balance of all levels and economic security of a territory, as well as the issues of maintaining the balance of the budget systems of the regions with a pronounced source of raw materials remain understudied. The lack of knowledge on the said problems determines the relevance of the present topic.

\section{Theoretical framework}

At present, the existing researches suggest various approaches to ensuring economic security of a region.

The authors of (Semenova, Bukharova, Samusenko, 2015) consider economic security as a package of measures for continuous development and improvement of the regional economy, including counter-action against any external and internal threats.

In their article "Analysing Approaches to the Regional Socio-Economic Security Processes Assessment" the authors of (Chichkanov, Beliaevskaia-Plotnik, 2016) come up with the following conditions of economic security: 
“...

- expansive reproduction of economic and social infrastructure (regional economy);

- prevention of any critical energy, food, medical and other dependence on fuel and essential goods;

- maintenance of the sufficient level of satisfaction of the people's social needs, standards and guarantees;

- provision of legal security to persons and businesses".

However, in our opinion, the listed conditions are rather a consequence of exposure of the regional socio-economic system to governmental control, which includes, inter alia, balancing the regional and municipal budgets. Therefore, the conceptual approach to the economic security of the region is underlaid by balancing regional and municipal budgets through generation of a multi-factor development model by means of creation of a diversified economic structure in the territory of the region (Luk'ianova, Liutykh, Kononova, 2015). In this case, economic security concept includes the constitutional guarantees of the regional population's rights based on the budget system equilibrium and prevention of any disproportion in allocation of finance to certain branches in the socio-economic development of the territory.

Budget equilibrium may be achieved through various approaches. The author of (Omshanova, 2013) suggests the following summary of the well-balanced budget concepts existing in the theory of public finance:

"Representatives of the classical 'balanced budget' concept (A. Smith, W. Eucken, F. Hayek, M. Friedman, J. Buchanan) justified the restriction of governmental control and the need for annual budget balancing, neutrality of budget and its independence of the reproduction processes of the state.

The second concept of the 'cyclically balanced budget' (E. Lindahl, G. Myrdal, B. Ohlin) connect the budget balance to the phases of the economic cycle and substantiate the need for an anti-cyclic budget policy implementation.

The third concept of 'functional finance' (J. M. Keynes, P. Samuelson, A. Hansen, J.K. Galbraith, R. Musgrave) prove the priority of the public finance objective in the achievement of macroeconomic balance, even if the interference of the state manifested in active budget policy causes the budget deficit".

To our mind, in the current conditions none of the concepts presented above can ensure the regional budget balance as a tool of economic security on its own, as the complicated geopolitical situation, instability of the commodity and financial markets 
require activation of the regulating function of the state; however, it is still important to observe the market economy principles, implying the preservation and development of competitive environment to provide consistent development of all parties of the economic relations.

\section{Statement of the problem}

Maintenance of economic security in the region through the balance of the regional and municipal budgets is a comprehensive task, which requires involvement of the governmental authorities, business representatives and local population presenting human capital as a specific value, into the socio-economic development process.

Let us study the opportunities of balancing the regional and municipal budgets based on one of the largest entities of the Russian Federation, the Krasnoyarsk Territory (Krai).

\section{Discussion}

Statistic information analysis (Federal State Statistics..., 2019) showed that socioeconomic development of the Krasnoyarsk Territory is extremely uneven. The Territory occupies the area of 2.4 million sq.km., with 61 municipal districts and municipal okrugs, that differ from each other in size, population, infrastructure development and, most of all, economic development level. Thus, the industrial output per capita in the city of Norilsk for the year 2017 constituted 2.87 million Roubles, in Krasnoyarsk 0.323 million Roubles, in Severo-Yeniseisk District - 6.5 million Roubles, in Bogotol District with the population of 9946 people and area of 2992 sq.km.- 0.038 million Roubles, in Idrinsky District with the population of 11411 people and area of 6070 sq.km.- 0.019 million Roubles, in Evenkia Municipal District with the population of 15279 people, area of 763197 sq.km.- 0.217 million Roubles. The uneven development is also proven by the analysis of municipal entities' expenses per capita. Bogotol District expenses per capita of 42.8 thousand Roubles are covered by the own revenues of 2.03 thousand Roubles; to finance the rest, 405.5 million Roubles is allocated from the regional budget. From Evenkia Municipal District, the figures are the following: expenses per capita count 376.3 thousand Roubles, covered by the own funds in the amount of 23.6 thousand Roubles per capita, and to finance the rest, 5.4 billion Roubles are allocated from the regional budget. It should be considered that the subject matter is the operating expenses, since the dominating share of capital expenses in the municipalities financed from the regional budget is carried out by the Government of 
the Region directly. Out of 61 municipal entities, 49 are subsidized. Consequently, the regional budget succeeds to fulfil its most important function, i.e. re-distribution of the consolidated regional budget, equalizing the fiscal capacity of the territories, making capital investments into a great number of the municipal entities.

This way, the regional budget is intended to equalize the expenses of the territories by re-distributing the income. In the year $2017,86 \%$ of the regional budget, including donation funds in the amount of 16.1 billion Roubles, is generated in the territories of 12 municipal entities. At that, a relevant share (31.5\%) of the regional budget is contributed by the economy of Krasnoyarsk. Tax revenues into the consolidated budget of the Krasnoyarsk Territory from the city of Krasnoyarsk in the year 2017 reached 62.8 billion Roubles, including 51.7 billion Roubles of income into the regional budget and 10.3 billion Roubles of income into the municipal budget.

It may be stated that the municipal and regional budgets act as integral parts of the unified consolidated budget; then the changes in the scale of the municipal budget make a relevant impact on both the consolidated and regional ones.

Such a relevant contribution into the regional budget development underlies the need for the city of Krasnoyarsk to solve a double task: balancing its own deficit budget and stabilize the deficit budget of the Territory. At that, according to the Ministry of Finance of the Russian Federation, the public debt of the Krasnoyarsk Territory reached 106.5 billion Roubles in 2018. It is the second largest value in the Russian Federation after the Krasnodar Territory (over 120 billion Roubles). Among the regions of the Siberian Federal District, the absolute debt of the Territory is the greatest. The last year's deficit of the regional budget constituted 1.8 billion Roubles; the deficit of the budget of the city of Krasnoyarsk is around half a million Roubles, with the municipal debt exceeding 12 billion Roubles. This way, search for the balancing tools for the budget of one of the stakeholders in the regional budget development is an extremely important task for the region.

Krasnoyarsk is one of the young million-plus cities of our country. The millionth citizen was born in spring 2012, after which the population reached 1.083 million in 2017. The population growth proves that the city is developing, that it attracts both locals and migrants (there is both natural population growth and positive migration balance), unemployment level is at its historical minimum; there are prospects for the younger generation. However, the maximal number of jobs are concentrated in the spheres of trade, service and catering.

As of 2017, among the own income of the municipal budget of the city of Krasnoyarsk there are the following taxes: land tax, unified tax on imputed income, 
personal property tax, personal income tax with the rate of $30 \%$, income tax with the rate of $5 \%$, as well as rent payments, payment for the rent right for construction, right for advertisement placement, income from municipal property privatization. The total volume of the own income of the municipal budget for the year 2017 constituted 13.8 billion Roubles, including 3.5 billion Roubles of non-tax income of the municipal budget. The municipal budget income volume has hardly changed within the period from 2012 to 2017. It should be noted, however, that during this period some changes into the inter-budgetary relations have been introduced to redistribute $10 \%$ of the individual income tax and $15 \%$ of the income tax in favour of the regional budget. If we assume that the deduction rate remains at the level of 2011, the municipal budget income would be 18.9 billion Roubles, i.e. increase by $37 \%$ during the five-year period.

Nevertheless, Krasnoyarsk budget is one of the most sufficient budgets of the comparable Siberian and Far East cities from the point of view of expenses. As of 2016, the expenses per capita constituted 25.5 thousand Roubles, and this value is next only after Kemerovo and Novokuznetsk, where it constitutes 32.2 and 31.4 thousand Roubles respectively. The value of capital expenses per capita, 4.7 thousand Roubles, is second to the budget of Tomsk, where the value equals to 5.2 thousand Roubles. At all that, from the point of view of own income, the city of Krasnoyarsk is one of the leaders among other Siberian and Far East cities with the income exceeding 13 thousand Roubles per capita, being ahead of Kemerovo, Novokuznetsk, and Tomsk, where this value varies around 10 thousand Roubles per capita.

Planning the budget of a municipal entity, the local authority bodies of Krasnoyarsk should refer to the restrictions implied by the regional law on inter-budgetary relations. The budget policy of the local authorities of the city during the period of 2012-2017 was oriented on solving the tasks connected with the city maintenance and development. The expenses were covered by the budget income; the expenditure budget was optimized by cutting down the irrational expenses and development of municipal and private partnership practice.

As a rule, in the modern conditions the tasks faced by the municipality challenge its resource capacity. It is caused by the unbalanced authority of the government bodies as a whole and the volume of public resources. For the overwhelming majority of municipalities, the problem is aggravated by the irrational network of governmental institutions established in the controlled economy period, suffering from $100 \%$ physical wear. In the current conditions, the key element of ensuring 
the budget system balance is the municipal-private (public-private) partnership. In the period of 2012-2017, some municipal-private partnership projects have been launched in Krasnoyarsk.

To provide pre-school education service to children aged from 3 to 7 years old, a project on "procurement" of places at private kindergartens followed by providing them to children on the waiting list under the conditions equal to those of the municipal nursery institutions was started. The places were "procured" in the process of a bidding campaign with the starting price of 9000 Roubles per month (for parents the monthly fee did not exceed 1500 Roubles per month). By the year 2017, 3700 vacancies had been procured in the private kindergartens, a part of which had acquired an education activity license.

Another partnership experience was the public transport fleet renovation project. Over $60 \%$ of passenger traffic in town is provided by private companies. To increase the transportation quality, to improve its environmental category and replacement of the fleet with newer vehicles, in the year 2016 the Administration of the city announced a bidding campaign for operation of 40 municipal public transport routes $(50 \%$ of the total number of routes) within five years. As a result, in the first month of the campaign around 400 vehicles of the fleet were replaced; later, this number reached 400 . The cost of modernization carried out by the commercial transport companies exceeded 3 billion Roubles.

Beautification and landscaping form one of the main tasks of the municipality. It was also solved through the municipal-private partnership. Three public parks were created exclusively at the expense of local entrepreneurs; the total cost of the project exceeds 150 million Roubles.

Dilapidated housing is one of the most acute problems faced by the country. Krasnoyarsk has successfully completed a number of municipal-private partnership projects that made a great contribution into the resolution of the problem.

In the city there are over 1300 actually lapidated houses with over 13000 families in need for new accommodation. The consolidated budget is insufficient for the state to solve this problem within an acceptable period of time. A solution is a built-up areas' development. Within the years 2014-2017, the municipal authorities have held 13 bidding campaigns, which facilitated total or partial rehousing of the people into suitable dwellings at the expense of the bidder organizations. As a result of the bidding, it is expected to rehouse over 500 families residing in over 50 dilapidated barracks located in the territories of the future construction sites. 
Another form of municipal-private partnership is deferred payment practice, which is, basically, a form of credit provided to the municipality by the construction companies in order to facilitate the resolution of such basic tasks of the city as overhaul of schools and kindergartens, reconstruction and maintenance of the road network and yards, constructions of public sport grounds.

The total result achieved through the set of budget balancing-oriented measures taken from 2012 to 2017, exceeded 7 billion Roubles. A relevant equalizing factor was involvement of funds from higher-level budgets. As of 2017, the volume of subsidies provided to the city from the regional budget constituted 4.335 billion Roubles, which is 0.8 billion Roubles less than the amount of income redistributed from the municipal into the regional budget as a result of changes in the inter-budgetary relations' regulations.

The efficiency of the municipal-private (public-private partnership should be assessed with consideration of the payback of the projects delivered with such mechanism. An example is the payback of the project on nursery school and pre-school education service for children aged from 3 to 7 years old, previously mentioned in the present article. The opening price for one place at a private kindergarten under the bidding campaign held by the city administration constituted 9 thousand Roubles per month; therefore, the maximum annual expenses equalled to 108 thousand Roubles per year with no capital expenses.

Notice that according to the present construction practice of Krasnoyarsk, the average cost of construction of one place at one nursery or pre-school education institution constitutes 1.1 million Roubles, with its annual maintenance cost being 91.78 thousand Roubles per year. Therefore, the difference of operating expenses for the maintenance of one place is only 16.22 thousand Roubles per year. The capital expenses for the creation of one place exceed this difference by 68 times, i.e. all acceptable standards of capital expense payback. Consequently, the municipal-private partnership project for providing children with pre-school education may be considered effective.

However, the problem of disbalanced municipal budget, and, therefore, disbalanced regional budget cannot be solved solely through expense optimization.

The research has revealed that the main sources of income for the regional and local budgets are individual income tax and revenue tax. According to the statistics for the year 2015 (Federal State Statistics..., 2019), the individual income tax share in the budget of Moscow is $41.6 \%$. The average value for Russia is $30.2 \%$. In the regional budget of the Krasnoyarsk Territory, the share of the individual income tax is $27.1 \%$, which is the $44^{\text {th }}$ among other regions of the country. The share of the revenue tax in 
the budget of the Krasnoyarsk Territory is $31.46 \%$, which is higher than the average Russian value of $22.6 \%$.

Revenue and salary are the main components of the added value (gross regional product) which is traditionally considered to be the basic regional development indicator. The Krasnoyarsk Territory has high GRP values. The gross regional product (gross added value of the capital goods price) in the Krasnoyarsk Territory constituted 1.616 trillion Roubles in 2015, 565,272.3 Roubles per capita, which is the $9^{\text {th }}$ largest value in the Russian Federation. It should be noted, however, that among the ten leader regions with the greatest GRP per capita except for Moscow and Saint Petersburg, all other regions have a pronounced raw materials-oriented economy, and the Krasnoyarsk Territory is one of them. In the Krasnoyarsk Territory, over one quarter of the all shipped products, performed works and rendered services is generated by the extractive industry, predominantly fuel and energy mineral mining. Even though $64.18 \%$ of the industrial product is generated by the processing branch, around one half of it belongs to metallurgy and metal product manufacturing; the share of other process industries is irrelevant (Kononova, 2015). It should be remarked that at a relatively high GRP per capita the specific value of the own income in the regional budget is lower than that of some regions with much lower value of GRP per capita, which is caused by the domination of low added value branches in the industrial system of the region.

Salaries and income of businesses are the basic values that characterize the produced added value. Analysing the mentioned indicators, it is important to consider both extensive and intensive factors that impact their values. The extensive factors for mineral extraction industry are: product volume growth, price trend fluctuations; the intensive factors are the changes in production technologies related to deep mineral processing, changes in the revenue proportion between the structural subdivisions of a consolidated taxpayers' group. The extensive factors for the process industries and service activities are the changes in production volumes and number of jobs; the main intensive factor is the productivity of labour and changes in the revenue proportion between the structural subdivisions of a consolidated taxpayers' group.

Analysis of salary statistics by regions of the Russian Federation for the period from 2000 to 2016 demonstrates that the average accrued wages of employees for the economy as a whole and in the Krasnoyarsk Territory in particular grows the average value lower than that in Moscow and the majority of the regions. For instance, if this value growth rate for the years 2000-2016 was 16.5 times, for the Territory it was only 11 . There are only two regions where this value is lower: the Khanty-Mansi 
Autonomous Okrug and the Yamalo-Nenets Autonomous Okrug, where it equals to 7.5 and 9.3 respectively. It is worth noticing that within the period 2000-2014 there was a tendency to equalizing the average wage growth rates between the regions of Russia, and in the last three years this value growth rate in the majority of regions has been insignificantly different from the average national one. The average growth rate for the years 2014-2016 for Russia was $13 \%$; in the Krasnoyarsk Territory, it was $12.5 \%$. There were only a few regions that formed an exception: Moscow with the value of $16.6 \%$ and Saint-Petersburg with 19.6, Arkhangelsk Oblast - $14.6 \%$, Leningrad Oblast $-14 \%$, Volgograd Oblast $-16.3 \%$, the Republic of Mordovia - 14.1, the Mari El Republic - $13.8 \%$, the Udmurt Republic - $13.9 \%$, Ulyanovsk Oblast $-14.4 \%$, the Kamchatka Krai - $15 \%$, Sakhalin Oblast - $18.3 \%$. If we do not consider the two latter regions, where the wage growth rate is caused by expansion of mineral extraction at the newly developed deposits, it may be suggested that the growth is connected mostly to the establishment of new processing enterprises. However, analysing the wage values in the Krasnoyarsk Territory, we see that in comparison with the average regional values the faster growing wages for the last 7 years are in the spheres of agriculture, fuel and energy related mineral mining, other mineral mining, wood processing and wood goods production, metallurgy, ready metal products manufacturing, electric and optical equipment production. This information proves the assumption that today the region is developing under the "as usual" scenario; if the regional economy structure is not modified in favour of economic activities with higher added value, budget balance will not be achieved.

The results of the conducted specific added value data per one employee of a number of large companies in Krasnoyarsk demonstrate that for the process industries this value exceeds the same value for wholesale and retail, hospitality and catering and others by $5-10$ times. At that, in the total amount of around 800 thousand jobs occupied in the region, jobs in the maximum added-value industries (for example, machinery and equipment production) constitute only 21 thousand. The growing number of jobs at the enterprises forming high added value level is one of the ways of development of a stable source for refilling the consolidated budget of the region. Therefore, the development of process industry enterprises is the priority in the formation of the mechanism for balancing the consolidated budget of the city and the region.

This way, one of the key tasks of balancing the regional and municipal budgets of the Krasnoyarsk Territory may be diversification of the industrial sector through the development of high added value enterprises, implementation and commercialization 
of innovative technologies, creation of an efficient interaction system for the science and education, industrial and governmental sectors, as well as development of small and medium-sized businesses involved in various business processes and satisfying the needs of large regional enterprises (Luk'ianova et al., 2018).

We suggest considering development of machinery and equipment production as one of the possible diversification options. The future of this economic sphere in the region is determined by the arrangement of an oil production cluster in Krasnoyarsk. Exploration of new oilfields creates a need for a larger amount of oil production, treatment and transportation equipment. Based on the forecasted volumes of oil production in the Territory, possible exploration of the shelf projects and based on the total production projects volume of 25 million tons, the forecasted amount of investment for five years reaches 1 trillion 200 billion Roubles. $45-48 \%$ of this volume falls under infrastructure (equipment) (Kriukov, 2018). If the assumed localization of production is $10 \%$, the production amount for five years is expected to count 54 billion Roubles. As the machinery and equipment production sphere values are: material expenses: $55 \%$, wages $15 \%$, uniform social tax: $5.3 \%$, depreciation: $1.7 \%$, other expenses: $6.7 \%$, cost effectiveness: $16.3 \%$, the individual income tax yield into the consolidated regional budget will achieve 1053 million Roubles, and the yield of income tax will constitute 1496 million Roubles.

\section{Conclusion}

Therefore, the research has shown that a great role in the development of a stable well-balanced consolidated regional budget structure is played by the structure of economy in the region. An integral part of creation of the industrial production structure based on high added value economic activities is the qualified staff training and human potential development. Increasing attractiveness of engineering departments in the higher education system, expanding number of scholarships provided to such departments lead to the growing number of graduates employed in high-tech industries within the region and, in the long run, bringing greater yield into the consolidated budget of the territory, than, for example, the graduates employed in the spheres of service, trade, catering or hospitality. Consequently, the higher education system oriented at the training the staff for high added value industries and creation of jobs at such enterprise forms the foundation for the stable income of the consolidated budget of the region.

Facilitation of economic security of the region through balancing the regional and municipal budgets requires concentration of the governmental control on the 
development of promising economic activities from both the perspective of GRP and the formation of a diversified and sustainable economic structure, as well as optimization of the expenditures of budgets of all level through restriction of capital expenses with the help of the municipal-private and public-private partnership mechanisms.

\section{References}

Akindinova, N., Cherniavskiy, A., Chepel', A. (2016). Regional'nye biudzhety v usloviiakh krizisa: mozhno li dostich' sbalansirovannosti? [Regional Budgets in a Crisis: Is It Possible to Balance?]. In Voprosy ekonomiki [Questions of Economics], 10, 31-48.

Chichkanov, V.P., Beliaevskaia-Plotnik, L.A. (2016). Analiz podkhodov k otsenke regional'nykh protsessov sotsial'no-ekonomicheskoy bezopasnosti [Analysis of Approaches to the Assessment of Regional Processes of Socio-Economic Security]. In Ekonomika regiona [Regional Economy], 3, 654-669.

Decree of the President of the Russian Federation of 31.12.2015 No. 683 " On National Security Strategy of the Russian Federation" (2019). Available at: http://publication. pravo.gov.ru (accessed 20 February 2019).

Federal State Statistics Service Department for the Krasnoyarsk Territory, the Republic of Khakassia and the Republic of Tuva (2019). Available at: www.krasstat. gks.ru (accessed 20 February 2019).

Federal State Statistics Service Department (2019). Available at: www.gks.ru (accessed 20 February 2019)

Grib, S.N., Makarova, S.N., Maslodudov, D.A. (2012). The Krasnoyarsk Agglomeration in the System of Inter-Budgetary Relations Between the Russian Federation and the Krasnoyarsk Krai. In Zhurnal Sibirskogo federal'nogo universiteta. Seriia: Gumanitarnye nauki [Journal of the Siberian Federal University: Humanities Series], 10, 1500-1510.

Kononova, E.S. (2015). Vozmozhnosti razvitiia otdel'nykh otrasley promyshlennosti s tsel'iu perekhoda regiona syr'evoy napravlennosti $\mathrm{k}$ ustoychivomu razvitiiu (na primere Krasnoiarskogo kraia) [Opportunities of Individual Industries Development to Switch a Raw Materials Region to Sustainable Development (Based on the Krasnoyarsk Territory)]. In Ekonomika v promyshlennosti [Economy in Industry], 2, $106-110$.

Kriukov, V., Tokarev, A. (2018). Spatial Dynamics of the Oil and Gas Field Services Sector: Global Trends and Lessons for Russia. In Regional Research of Russia, 3, 248. 
Kuklin, A.A., Naslunga, K.S. (2018). Metodicheskie osobennosti otsenki sostoianiia regional'nykh biudzhetov [Methodical Peculiarities of the Regional Budget Assessment]. In Ekonomika regiona [Regional Economy], 2, 395-407.

Luk'ianova, A.A., Liutykh, Yu.A., Kononova, E.S. (2015). Puti povysheniia effektivnosti mekhanizma gosudarstvennogo regulirovaniia sotsial'noekonomicheskogo razvitiia regiona (na primere Krasnoiarskogo kraia) [Improving Governmental Control Mechanism of the Socio-Economic Development of the Region (Based on the Krasnoyarsk Territory)]. In Vestnik Sibirskogo gosudarstvennogo aerokosmicheskogo universiteta im. akademika M.F. Reshetneva [Bulletin of Reshetnev Siberian State Aerospace University], 4, 1038-1044.

Luk'ianova, A.A., Kononova, E.S., Beliakova, E.V., Smorodinova, N.I., Beliakova, G.Y., Polezhaeva, G.T. (2018). Possibilities for Sustainable Social and Economic Development of Northern Territories. In International Journal of Ecological Economics and Statistics, 39(2), 90-95.

Makarova, S.N. (2012). Development of Methodological Principles of Program Budgeting for Effective Management of Public Finances. In Zhurnal Sibirskogo federal'nogo universiteta. Seriia: Gumanitarnye nauki [Journal of the Siberian Federal University: Humanities Series], 10, 1409-1418.

Omshanova, E.A. (2013). Sbalansirovannost' biudzhetov: otsenka i instrumenty [Balanced Budgets: Evaluation and Tools]. In Sovremennye nauchnye issledovaniia $i$ innovatsii [Modern Scientific Research and Innovation], available at www.web. snauka.ru/issues/2013/11/28509

Pechenskaia, M.A., Uskova, T.V. (2016). Mezhbiudzhetnoe raspredelenie nalogov v Rossii: kontsentratsiia polnomochiy ili detsentralizatsiia upravleniia [Inter-Budgetary Distribution of Taxes in Russia: Concentration of Powers or Decentralization of Management]. In Ekonomika regiona [Regional Economy], 3, 875-886.

Semenova, A.R., Bukharova, E.B., Samusenko, S.A. (2015). Vliianie prostranstvennogo neravenstva $\mathrm{i}$ asimmetrii regional'nogo razvitiia na ekonomicheskuiu bezopasnost' resursnykh regionov Rossii (na primere Krasnoiarskogo kraia) [Influence of Spatial Inequality and Regional Development Asymmetry on the Economic Security of Resource Regions of Russia (Based on the Krasnoyarsk Territory)]. In Zhurnal Sibirskogo federal'nogo universiteta. Seriia: Gumanitarnye nauki [Journal of the Siberian Federal University: Humanities Series], 11, 2621-2631.

Tabakh, A., Andreeva, D. (2015). Dolgovye strategii rossiyskikh regionov [Debt SStrategies of Russian Regions]. In Voprosy ekonomiki [Economic Issues], 10, 78-93. 
Zubarevich, N.V. (2016). Monitoring krizisa i postkrizisnogo razvitiia regionov Rossii [Monitoring the Crisis and Post-Crisis Development of the Regions of Russia], In: NISP, available at: www.socpol.ru/atlas/overviews/social_sphere/kris.shtml\#no36

Zubarevich, N. (2015). Regional'naia proektsiia novogo rossiyskogo krizisa [Regional Projection of the New Russian Crisis]. In Voprosy ekonomiki [Economic Issues], 4, 37-52.

\title{
Сбалансированность регионального \\ и муниципального бюджетов как инструмент \\ обеспечения экономической безопасности территории на примере Красноярского края
}

\author{
Э.Ш. Акбулатов, А.А. Лукьянова, Е.С. Кононова \\ Сибирский государственный университет \\ науки и технологий им. академика М. Ф. Решетнева \\ Россия, 660037, Красноярск, \\ пр. имени газетьл «Красноярский рабочий», 31
}

\footnotetext{
В современных условиях проблемь экономической безопасности соииально-экономических систем различного уровня находятся в сфере пристального внимания российских и зарубежных ученых. Особенно остро данные проблемы стоят перед территориями, имеющими выраженную сырьевую направленность и недостаточный уровень развития производств с высокой добавленной стоимостью. Экономическая безопасность города и региона не может быть обеспечена без учета отраслевой структуры экономики и сбалансированности бюджетов всех уровней. Важным индикатором сбалансированности бюджета является структура доходной части регионального бюджета, или, более точно, структура налоговых поступлений в бюджет, а также структура расходов.

В статье рассматриваются особенности формирования доходной и расходной частей региональных и местных бюджетов, анализируются наиболее типичные источники доходной части для различных типов территорий.

Авторы приводят анализ структуры консолидированного бюджета региона и ряда мунищипальных образований на примере Красноярского края. Рассматривается динамика доходов и расходов, исследуются ограничения, предусмотренные региональным законом о межбюджетных отношениях. В результате исследования авторами получены выводы об отсутствии сбалансированности анализируемых бюджетов, их несоответствии потребностям региона и, как следствие, о существующих угрозах экономической безопасности рассматриваемой территории.

Статья содержит рекомендации по развитию на территории Красноярского края видов экономической деятельности, учитывающих специффику исследуемого региона и способных повысить сбалансированность местных и регионального бюджетов.
} 
Ключевые слова: государственный бюджет, региональная бюджетная система, муниичипальный бюджет, планирование бюджета, сбалансированность бюджета, экономическая безопасность.

Научная специиальность: 08.00 .00 - экономические науки. 